\title{
Success factors behind Entrepreneurship during economic crisis: A study of Sam Office Furniture in Erbil-Kurdistan
}

\author{
Dr. Mohammed Ali Saleem Alozairi \\ Business Administration \\ Ministry of planning, Erbil-Kurdistan
}

\begin{abstract}
Entrepreneur has an essential role in the country's economy especially during economic crisis, being considered one of the main engines of economic growth, and an important contributor to creating new jobs and innovations. Identifying the main determinants of entrepreneurial activity is important for helping the decision makers in adopting adequate measures to support the creation and development of new businesses. The study was carried out in a private furniture company named 'Sam furniture company' in Erbil, the researcher was able to gather 112 questionnaires in order to test the developed research hypotheses. The findings revealed that the highest value obtained was by previous experience of entrepreneur in running furniture companies in Erbil on the other hand the lowest value of background education of entrepreneur in establishing and expanding a furniture company in Erbil.
\end{abstract} Keywords - Entrepreneur, Sam Furniture Company, Erbil, Kurdistan.

\section{INTRODUCTION}

Entrepreneurship researchers hold altogether different convictions about the idea of enterprise exercises and clarifications of its part in wanted financial advance (Bruton, et al., 2015). Notwithstanding, since Entrepreneurship is an unpredictable and dynamic marvel, distinct perspectives exist with respect to the components that truly goad it (Glaeser, et al., 2015). Henceforth, specialists should obviously set up the impediments and contentions whereupon they are basing their investigation. Propelled thinks about on Entrepreneurship need to investigate the cooperation between outer components, for example, entrepreneurial openings and training and national outlook toward enterprise; and individual elements, for example, business person's social skill and viability and their effects on entrepreneurial execution (Bae, et al., 2014). In late decades there has been a stamped increment in the enthusiasm for entrepreneurship as change facilitator both in cutting edge and developing business sector economies
(Fayolle and Gailly, 2015). Basic to the accomplishment of entrepreneurship are those qualities and characteristics connected to entrepreneurial conduct. While such attributes have been recognized, the inquiry stays with reference to how these qualities may contrast crosswise over nations because of such attributes as the populace, financial advancement, monetary opportunity and social measurements (Davidsson, 2015).

In spite of the fact that it is collectively acknowledged that entrepreneurship assumes a noteworthy part in financial advancement, the confirmation of this connection is astoundingly restricted. This might just be caused by the way that this connection requires the affirmation of middle of the road forms. Entrepreneurship is firmly identified with private ventures and mechanical change. There is observational confirmation of the positive impact of the nearness of independent companies on monetary development. So as to enhance allotment proficiently, possibly fruitful entrepreneur ought to be animated in their exercises (Ács, et al., 2014).The economic significance of furniture enterprise has expanded fundamentally in late decades, since vast organizations are progressively focusing on center abilities and executing mass lay-offs (Decker, et al., 2014). In addition, numerous researchers have perceived and exhibited the essential pretended by furniture businesses as a driving motor of development, work creation, aggressiveness in worldwide markets and the general wellbeing and welfare of economies both broadly and globally. For instance around 85 for each penny of new occupations in the developed countries are made by private venture (Terjesen, et al., 2016). As the entrepreneurial movement and Furniture businesses are believed to be progressively fundamental to monetary advance, it is imperative to think about how furniture entrepreneur can upgrade their execution and guarantee their survival in the turbulent economic condition. Adapting to such cruel conditions may expect firms to exhibit extraordinary capacities, inward assets or practices, for example, 
creativity, adaptability or versatility. In that sense the key administration and business enterprise writing may offer valuable ideas to use when searching for conceivable cures or improvements for association's odds of performing amid monetary emergencies (Boh, et al., 2016).Piperopoulos and Dimov, (2015) brought up that few unmistakable key introductions of organizations, for example, advertise, client, learning, innovation, and entrepreneur have increased significant consideration from the two directors and administration researchers. A few examinations have given confirmation that one of these introductions alone and furthermore the connection between the introductions or diverse mixes of the introductions may give a wellspring of elite or upper hand for firms (Stephan, et al., 2015). As these key introductions are noteworthy drivers of an association's execution, we center here around one of them, all the more particularly on business visionary. In late decades the idea of entrepreneur has pulled in extensive consideration in the field of enterprise examine.The most part allude to an association's affinity to be creative, to be proactive and to go out on a limb. The entrepreneur idea is generally utilized as a part of the field of enterprise. For example Arend, et al., (2015) called attention to that in excess of 85 investigations of entrepreneur have been led, suggesting that the calculated significance of entrepreneur visionary is generally acknowledged and that it is broadly considered as applicable idea and a foundation in the writing on firm-level enterprise. Most entrepreneurs considers have concentrated on the entrepreneur execution relationship and have discovered that embracing entrepreneur related entrepreneurial practices will help firms to make or manage an abnormal state of execution (Read, et al., 2016).

\section{LITERATURE REVIEW}

\subsection{The concept of entrepreneurship}

The idea entrepreneur has been altered and archived to a great extent by learned people from the created countries, for example, developed countries. Commentators bring up that next to zero noteworthy commitment on the creation of this idea was gotten from creating and minimum creating nations (Siqueira, et al., 2016). Be that as it may, this does not suggest that this idea began in the created nations rather than the creating one. This may similarly pre-gathered among others, that before the beginning of the human advancement in the creating and slightest created countries, specialists in such country states had no appropriate stage to uncover their scholarly conceptualization of entrepreneur enterprise. Thus, specialists from creating and slightest created countries have been credited with the speculations that were reversed by master from created country. Consequently, emulating the perspectives and encounters of the prevailing hypotheses and practices from created countries, with little reference to their commonsense application to their separate nations (Choi \& Majumdar, 2014).

Table.1: Entrepreneurship definitions

\begin{tabular}{ll}
\hline Author & Definition \\
\hline Duru (2011) & The whole idea about entrepreneurship is about self-employment, which will \\
& generate employment opportunities to others that must work with him as he \\
cannot work alone. & Entrepreneurship is a process that involves individuals and groups of \\
individuals seeking and exploiting economic opportunities. & Entrepreneurship is a process of creating something new with value by devoting \\
the necessary time and effort, assuming the accompanying financial, psychic \\
Hisrich et al. (2005) & $\begin{array}{l}\text { and social risks and receiving the resulting rewards of monetary and personal } \\
\text { satisfaction and independence. }\end{array}$ \\
Wickham (2004) & $\begin{array}{l}\text { Entrepreneurship is referred to as a function, activities and actions associated } \\
\text { with the perception of opportunities and creation of organizations to pursue } \\
\text { them. } \\
\text { Timmons and Spinelli (2004) } \\
\text { Entrepreneurship as a way of thinking, realizing and acting that is opportunity } \\
\text { obsessed, holistic in approach and leadership balanced. It results in the } \\
\text { creation, enhancement, realization and renewal of value, not just for owners but } \\
\text { for all participants and stakeholders. } \\
\text { Entrepreneurship is the creation of an innovative economic organization (or } \\
\text { network of organizations) for the purpose of gain or growth under conditions of } \\
\text { risk and uncertainty. } \\
\text { Entrepreneurship is the process of creating or seizing an opportunity and } \\
\text { pursuing it regardless of the resources currently controlled. }\end{array}$ \\
\hline
\end{tabular}


It is comprehended that was the main hypothesis of enterprise. This hypothesis gave an essential view that enterprise is a critical piece of the market framework and is related with entrepreneurial exercises, for example, purchasing and offering of products and ventures. McKeever, (2015), they promote contended that the breaking points of supply are fundamentally the boundaries to the section and that may incorporate the important accounts to finance the entrepreneurial undertaking

Acs, et al., (2018) proposed that hazard taking is a key factor in recognizing entrepreneur from chiefs. It is trusted that entrepreneur go for broke particularly in zones where they have control or skills in understanding the benefit. Numerous examinations have included hazard taking as a noteworthy entrepreneurial trademark. Coviello, et al., (2015) affirmed that entrepreneur excitedly embrace the obscure and unverifiable conditions, along these lines the entrepreneurial slanted people are required to show more resistance of equivocalness than others. To the extent ingenuity is concerned, they proposed that it is the point of convergence of business enterprise and a fundamental business person trademark. For sure entrepreneurial literary works demonstrate those entrepreneurs are altogether more inventive than non-entrepreneur (Fitz-Koch, et al., 2018). Entrepreneur visionaries' identity qualities have additionally been distinguished to have effect on hierarchical execution. Concentrates additionally found that identity attributes, for example, locus of control and uncertainty resilience impacted the business achievement specifically and the business procedure in a roundabout way (Nabi, et al., 2018). Entrialgo (2018) later added statistic factors to his examination and found that identity qualities have coordinate impact on the achievement of African entrepreneur. In spite of the fact that reviews on identity characteristics have assumed an essential part in adding to the accomplishment of entrepreneur around the world, by and by, identity attributes have been scrutinized both on hypothetical and exact ground in the investigations of enterprise. Hornsby, et al., (2018) they stated that "Who" is the wrong inquiry, yet rather the identity of business person is just identified with the achievement of business start-up through more particular intervening procedures. This is because of the way that these components are not important if there is no move and activity made by the entrepreneur. Shelton \&Minniti, (2018) think about directed on a gathering of representatives uncovered that those with higher individual activity performed altogether better in the work environment. Research on individual activity focus on the self-beginning nature of entrepreneur: how they seek after progress with their proactive state of mind, how to look for and get a handle on circumstance with their proactive approach, and how to discover any arrangements or necessities to conquer hindrances to accomplish their objectives (Henry, et al., 2018). Entrepreneur with high activity can remain in front of their rivals, and are good example individuals without tertiary instruction, negligible mechanical and administrative experience, and with next to zero business presentation. Also, competency is one of most significant components to guarantee the accomplishment of new business wanders. The entrepreneur confronted considerably more noteworthy test when they have effectively convey their associations to development and as the organization moves into this stage, it encountered what spectators allude to as vital reflection point (Hlady-Rispal \& Servantie, 2018). A vital reflection point speaks to a period in the life of the business when the major activities have significantly changed. As indicated by scholars, associations advance through steady, unsurprising periods of improvement known as life-cycle stages. In the start-up arrange, the organization is worried about creating the item or administrations, setting up a market specialty, drawing in new clients, and assembling and promoting of the item (Coviello \& Tanev, 2017). Once the organization starts to develop quickly, it should have more formal structures and coordination because of the expansion in utilitarian exercises. In the development arrange, the entrepreneur is compelled to center around the long haul solidness while keeping up the creative and entrepreneurial soul that made it fruitful in any case. As the establishing individuals from the organization, the entrepreneur assumes a vital part in the long haul business accomplishment of another wander. The entrepreneurial pioneer champions the vision of the organization and motivates others, for example, financial specialists, investors, brokers, clients and representatives to help the vision. Be that as it may, sooner or later in time, the organization will proceed to develop and the originator must spotlight and underscore on various territories of skills and abilities so as to lead the organization to long haul business achievement. As per tried and true way of thinking, because of the poor useful capabilities of the originators, they are commonly supplanted by proficient supervisors who have the experience and the fundamental abilities required to deal with the organization when it starts to travel from a start-up stage to a development arrange organization (Huq \& Gilbert, 2017). Berglund \&Korsgaard, (2017), found no proof that expert supervisors performed preferable in high-development organizations over the first originators. They watched that numerous originators could figure out how to oversee development viably. Along these 
lines, the presumption that an expert director must be utilized may never again be substantial. This investigation tested the standard way of thinking by uncovering the procedure by which effective entrepreneur change themselves into proficient supervisors. While thinks about found that organizers could have the abilities to perform similarly well as expert administrators, there are not very many investigations on the similitude and the zones of capabilities these fruitful entrepreneur and directors concentrated on for development arrange organizations. Numerous examinations found that dominant part of the business disappointment were because of the absence of administration abilities or capabilities (Lerner, et al., 2018). Stuetzer, et al., (2017) considered ten flopped highinnovation firms and presumed that there were three noteworthy explanations behind the disappointment: 1) money related challenges, 2) item/advertise issues and 3) administrative issues. Thus, entrepreneur who have the important abilities particularly in the zone of activities, fund, advertising and HR, and administration aptitudes required for the business will probably be effective at startup (Belz \& Binder, 2017). The territories of competency has been extraordinarily explored in most created nations, and most written works uncovered that they are decidedly identified with organizations at wander development, and in like manner, there is no writing discovered relating to such theme in Malaysia. In this way one of the points of this examination is to inspect the territories of useful capabilities that establishing entrepreneur concentrated on and adds to the achievement of overseeing organizations at development arrange. Aside from the capabilities said before, (Danakol, et al., 2017)found in their examination that interpersonal organization bolster is identified with both, survival and development of recently established organizations. A system approach expects that business person's capacity to sort out and facilitate arranges amongst people and associations are basic for beginning up an organization and business achievement. It was discovered that formal help sources were not really utilized; the organizations for the most part specified were banks (Campbell, et al., 2017). Support from casual system, for example, companions, relatives, past managers and associates have found to profit the business. Along these lines another point of this examination was to inspect to what degree informal organization bolster altogether add to the achievement of overseeing organizations at development arrange. In conclusion, questions have additionally been raised relating to the administration's part in supporting the entrepreneur both amid start-up and wander development. Numerous are uninformed of assets and projects gave by the administration, while some trusts it is difficult to acquire such help, others are just insensible of it. In examination with neighboring nations relating to these help programs, an article specified that the writing distributed by the Malaysian Industrial Development Authority gives off an impression of being distracted with interior bureaucratic concerns as opposed to the entrepreneur visionary's needs (Shelton \& Minniti, 2018).

\subsection{Main characteristics of Successful entrepreneur}

In view of my own involvement and an inquiry of the writing, the most vital qualities of a business person are having a solid hard working attitude, being exceptionally energetic, having enthusiasm and having a triumphant disposition. As anentrepreneur should give extensive entrepreneurial drive something to do to develop one's business, however one ought to be set up to work hardest amid start-up. One must be prepared to deal with long days (8-14 hours) and play out numerous capacities, including deals, advertising, obtaining, bookkeeping, HR, client benefit and numerous others. These capacities can be supplemented by a solid administration group, Board of Advisors, specialists and different consultants.

The key personality traits of successful entrepreneurs are:

- Willing to guarantee debts (entrepreneur) or sell idea in existing organizations

- Must be able to focus and refocus (limit distractions)

- Customer focus

- High risk / gambling mentality

- Persistence/ principled

\subsection{Success Factors of Entrepreneur}

McKenny et al. (2017) specified that basic achievement factors can be as exercises, occasions, conditions or conditions that require exceptional consideration of business person. As indicated by Huang \& Knight, (2017), every one of these components can impact business person accomplishment in either a constructive or adverse way, along these lines give an extensive approach that fundamentally center around clear up suspicions to prompt the adaptability that are impartial and help dissimilar idea. The greater part of scientists contended that attributes of business, qualities of business person, and firm procedures are among the inner elements that impact Furniture businesses achievement and development (Wiklund, et al., 2017). In this manner, this examination aggregate inside variables into three (3) classifications that to be specific 
attributes of Furniture businesses, qualities of entrepreneur, and entrepreneurial abilities.

\subsubsection{Age of the Entrepreneur}

Different asset has been affirmed the period of business person greatly affect business execution. Whereby, McKenzie, (2017), contended that age is by and large connected with moderate conduct, and in this way applies a negative effect on the business execution for three (3) reasons. Initially, a more established business person is less disposed to embrace inventive conduct or to acknowledge new thoughts. Besides, senior business person would be more joined to certain authoritative the present state of affairs. In conclusion, destinations identified with wage and expert security will create more judicious conduct. Therefore, from the past investigations it has been recommended that more youthful entrepreneur will be more disposed to end up a daring person and pioneer to develop their business (Hlady-Rispal \& Servantie, (2018).

\subsubsection{Gender of the Entrepreneur}

Blended outcomes have been accounted for in regards to gender orientation contrasts concerning entrepreneurial inspiration. As per a few investigations female and male entrepreneur were observed to be similarly inspired ( $\mathrm{Si}$, et al., 2018). In these investigations achievement was verifiably compared with inspiration to begin entrepreneurship; however no endeavor was made to quantify achievement straightforwardly or in a roundabout way. (Bae, et al., 2014), have guessed that the likelihood of various arrangement of components for men and ladies entrepreneur affecting their prosperity. (Belz \& Binder, 2017), have revealed that in view of various socialization examples of young ladies and young men, the vocation yearnings of two gender orientations are probably going to appear as something else; and that stretches out to goal to select entrepreneurial profession. A few creators have announced discoveries that recommend that impression of entrepreneurial achievement varied between two gender orientations. Female entrepreneur were discovered more prone to give more significance to social morals and subjective criteria of achievement (Bruton, et al., 2015), while male entrepreneur were discovered more inclined to underscore quantitative measuring sticks and monetary gauges to quantify their entrepreneurial achievement (Campbell, et al., 2017). Concentrates by (Campbell, et al., 2017), have investigated the meaning of achievement that was not constrained to monetary measures of execution. Entrepreneur's subjective discernment about their own particular achievement is most likely more important idea from their point of view. Support for such subjective measures of self-efficacy accomplishment among female entrepreneur was accounted for by (Choi \& Majumdar, 2014). Impact of gender orientation on the choice to begin another wander has been examined by (Coviello \& Tanev, 2017). It appears that the gender hole in business enterprise has limited amid the previous decade, however the offer of female entrepreneur occupied with wander making exercises was still similarly low in numerous nations as announced by (Davidsson, 2015), have detailed that gender orientation hole in human capital change contingent upon national culture, along these lines it is deceiving to accept that gender contrasts apply generally. (Decker, et al., 2014), have detailed in some nations think about that ladies overwhelmed in entrepreneurial exercises in 4 nations, to be specific, Japan, Thailand, Peru, and Brazil; while in outstanding 35 nations guys commanded the entrepreneurial exercises. Strangely the most imperative contrast between achievement of male and female entrepreneur was accounted for to be their administrative experience. Presence of moderately low extent of female entrepreneur when contrasted with male entrepreneur was accounted for by numerous creators. Gender contrasts as for development and achievement of big business were additionally detailed: female-claimed endeavors were found to fail to meet expectations on these two tallies. It was accounted for that absence of least important human and monetary assets were explanations behind relative underperformance and absence of accomplishment among female entrepreneur (Fayolle and Gailly, 2015). Relative absence of important work understanding, absence of administrative experience, and absence of independent work encounter were accounted for female entrepreneur when contrasted with their male partners by (Fitz-Koch, et al., 2018). Inspiration, objectives, and individual discernment about entrepreneurial achievement were impacted by gender orientation as revealed by (Glaeser, et al., 2015).These discoveries appear to infer that male and female entrepreneur are spurred in an unexpected way, have distinctive objectives, and measure their prosperity in an unexpected way. Understanding that preparation needs may be distinctive because of gender contrast, (Hlady-Rispal \& Servantie, 2018), inquired about reasonableness of tailor made preparing programs for female entrepreneur. (Huq \& Gilbert, 2017), have contended for including gender as an illustrative variable while contemplating entrepreneur. The discoveries of these examinations prompt acknowledgment that the presence of gender orientation contrasts are genuine; and such contrasts are probably going to have noteworthy impact on numerous parts of entrepreneurial action including accomplishment as business visionary. (Lerner, et al., 2018), have commandingly introduced gender orientation contrast 
related ramifications for female entrepreneur in relatively inciting terms as though Men and Women entrepreneur could be seen as two unique species. From hundreds of years, there are numerous writing has been distributed on the impact of gender orientation contrasts towards the business execution, yet blended outcomes are 31 generally created. As clarified by (Nabi, et al., 2018), in the vast majority of research directed in created nation there are no discoveries to demonstrate that gender orientation can be essentially connected with business execution, those that do are in the contradiction about climate ladies based firms are probably going to become quicker or slower. In any case, in creating nation there are several of gender orientation related difficulties to Furniture businesses execution are regularly recognized in those writing. As per (Read, et al., 2016), men are regularly confronted uneven rights and commitments that constraining works portability and troubling them with lopsided family duties. In the meantime, the investigation of (Shelton \& Minniti, 2018), inferred that ladies entrepreneur are frequently experience the ill effects of inadequate specialized skill and learning administration which prompt their low efficiency and intensity in the market. In addition, social limitations are additionally another obstruction that ruins the achievement of ladies in the lead of their issues. The finding above likewise upheld by analysts like ( $\mathrm{Si}$, et al., 2018), with contention that ladies entrepreneur continually confronting low level of human capital and less chances to create significant experience and subsequently experiencing issues in collecting assets.

\subsubsection{Education Background}

Relationship of entrepreneurial accomplishment with the education has been contemplated in the most recent decade in various settings and settings. The greater part of the discoveries reports a positive relationship of education with progress. Following passages examine a portion of the examinations revealing this relationship. (Siqueira, et al., 2016), have utilized separation to class as a variable for education and land accessibility as an instrument for business enterprise. They found that entrepreneurial comes back to education were impressive for at any rate a few gatherings of entrepreneur in (Stephan, et al., 2015), assessed the profits to instruction for entrepreneur. These endeavors were gone for measuring the impact of education on entrepreneur's prosperity. Entrepreneur visionaries who put additional time and cash in information obtaining were discovered more fruitful, while time lack was accounted for as the significant reason that entrepreneur gave for maintaining a strategic distance from to put resources into learning procurement (Terjesen, et al., 2016). It was additionally detailed that $81 \%$ of entrepreneur visionaries utilized "one day workshops" and "perusing proficient writing" as their best information refreshing procedure, just $18 \%$ entrepreneur revealed utilizing cash devouring and tedious formal instruction process.

Education is where information can be increased through educating, formal and casual getting the hang of, coaching, and guidelines that got by an individual (Bae, et al., 2014). There are a few investigations found that there is a nonattendance interface amongst education and entrepreneur execution (Belz \& Binder, 2017), opposite, a lot of concentrates found that the level of instruction positively affecting execution. At similar circumstances, (Boh, et al., 2016), likewise protects that the education level ready to build the entrepreneur' information about the business and industry, which will prompt change of entrepreneur's aptitudes and capacities. Correspondingly, (Campbell, et al., 2017), contended that formal instruction is a critical asset for entrepreneur by giving valuable specialized learning that accommodating in distinguishing business openings. According to (Choi \& Majumdar, 2014), education is one of the strategy to enhance firm limit through enhancing learning, aptitudes, teach, inspiration, critical thinking capacity, appropriate way and conduct, and fearlessness of business person in distinguish advertise opportunity and accumulate assets required to set up another wander. In any case, there are analysts discovered that in creating nations the impact of instruction on Furniture businesses execution is perplexing as the majority of entrepreneur and specialists are have a tendency to have generally low level of education than bigger firms do (Coviello \& Tanev, 2017).

\subsubsection{Previous Experience}

Past experience incorporates work understanding, business administration experience, and industry-particular experience (Danakol, et al., 2017). As indicated by (Davidsson, 2015), the more prominent the entrepreneur's past experience the higher their entrepreneurial quality as the experience included a learning procedure that enables entrepreneur in distinguish openings, to diminish their underlying start-up wastefulness, and in addition to enhance their ability in performing different undertaking. This is upheld by research of who contended that capacity to acclimatize understanding and gain from past experience are vital in impact entrepreneurial process, Individual that absence of working background may have lesser abilities and think that its more hard to build up a move business thought (Decker, et al., 2014). Subsequently, as indicated by (Fayolle and Gailly, 2015)most new firms are begun by entrepreneur who have 35 past experience that gave them 
mastery to recognize business open door and also create a superior items or administrations.

\subsubsection{Role of Family}

Fitz- Koch, (2018), has detailed impact of family, companions, and good examples on entrepreneur; however they were contemplating not the achievement but rather the entrepreneurial expectation. (Choi \& Majumdar, 2014), have shown effect of good example on entrepreneur visionaries, and has plot various systems through which such effects are made upon the entrepreneur visionaries. (Davidsson, 2015), have detailed about the significance of the family, extraordinarily father and mother, on entrepreneurial conduct. In an example of Japanese entrepreneur visionaries have announced impact of loved ones on entrepreneurial conduct. (Fayolle and Gailly, 2015), have detailed the impact of both family foundation and sexual orientation on entrepreneurial conduct. Male and female entrepreneurs were impacted contrastingly by their folks as revealed by (Fitz-Koch, et al., 2018), in an example contemplated entrepreneur as for inherited/hereditary impacts. They characterized shared natural impacts as "the degree to which experiencing childhood in a similar family makes individuals comparative". They additionally characterized non-shared-condition as "one of a kind situation that individuals encounter in spite of experiencing childhood in a similar family. Extraversion and neuroticism were utilized as two factors through which hereditary impacts were estimated to impact choice to start entrepreneurial movement. They found that female entrepreneur have shown more hereditary impact and zero shared condition effect on their inclination to end up entrepreneur. Conversely male entrepreneur have demonstrated zero hereditary impact yet more shared condition effect on their propensity to end up entrepreneurs. These discoveries have a tendency to hose the part of family foundation in the achievement of entrepreneur; and backings the individuals who propose 'nature' as the main thrust for people to end up entrepreneur. In any case, then (Glaeser, et al., 2015), have discovered that female entrepreneur' parental status has assumed a key part in building up females' discernment about their entrepreneurial achievement. This discovering underpins the impact of family factors on entrepreneurial achievement; and backings those for 'sustaining' the entrepreneur. (Henry, et al., 2018), have revealed, in an example of Brazilian entrepreneur, that various family related elements affected the choice to wind up business person; however they additionally announced that family related elements were not discovered identified with entrepreneurial achievement. Strikingly they discovered negative connection amongst progress and relatives of entrepreneur additionally running organizations.

Specialists (Hlady-Rispal \& Servantie, 2018), contended that family foundation is imperative to entrepreneur. Knowledgeable guardians frequently urge their youngster to be autonomous and confidence, whereby give on their posterity an early favorable position; while affluent guardians dependably advance in and help with start-up capital (Huq \& Gilbert, 2017). Besides, person who conceived in a family situation with privately-run company working will enhance the achievement of the specific individual, this can be demonstrated the finding of which specified that an adolescent who lives in a situation that imparts trust in entrepreneurial achievement will probably advance forward contrast and the individuals who are most certainly not (Lerner, et al., 2018).

\subsection{Economic and Entrepreneurship}

(Nabi, et al., 2018), characterizes the smaller scale ecological factors as "components or components in an association's quick region of activities that influence its execution and basic leadership opportunity". These elements incorporate client connections, provider connections, and contenders as in how to make an upper hand to win the war zone. I. Client Relationships Researchers, for example, (Shelton \& Minniti, 2018), concurred the long haul advantage of present and potential clients, and the significance of drawing consideration on client relationship administration. The practices in client relationship administration that will be break down in this paper included client faithfulness program, execution of Mobile Marketing, think about the changing on client socioeconomics, the use of direct promoting procedure, coordinate disconnected business into online stage, utilize SEO to track and investigate client request changes,), and turn into a "Brand of Choices".

Flexibility to go about as an entrepreneur is affected by monetary opportunity. Legacy Foundation and Wall Street Journal measure monetary opportunity of nations by such highlights of business condition as clear property rights, flexibility from debasement, restricted government spending and mediation to business, business flexibility, work flexibility, exchange opportunity, money related opportunity, speculation and budgetary flexibility. (Stephan, et al., 2015), show a pattern line that nations with higher GDP per capita likewise have higher whole of these financial flexibility segments. (Terjesen, et al., 2016), have contemplated entrepreneurial activities in various nations from 1990s to 2010 and set up positive and huge effect of low defilement on entrepreneurial passage, person's choice 
to wind up a business visionary. It is however likewise vital to comprehend which highlights of effective entrepreneur are seen to be vital in such nations, where bureaucratic methods entangle the way toward beginning another business. The World Bank every year assembles the working together record in light of information from June of the earlier year. This list measures effortlessness of establishing a business and beginning its tasks. World Bank likewise thinks about nations by the quantity of institutional and administrative changes actualized amid a year for enhancing business conditions. Number of changes likewise shows how steady or changing business condition has been amid a year. Diamond overviews have amid numerous years demonstrated that connection between GDP per capita and power of beginning time business enterprise isn't direct. In nations that have low per capita GDP individuals regularly begin their own particular business as they can't discover occupations in set up organizations. (Terjesen, et al., 2016), brings up that high association in such economies frequently reflects predominance of the need driven business. In further developed advancement driven economies the offer of new entrepreneur in the populace is lower yet they are all the more frequently determined by new business openings that they have found or made. Singular open door nexus has been a critical part of building up the hypothesis of business enterprise.

\section{METHODOLOGY}

The main purpose of this research was to analyze the relationship between success factors and entrepreneur during economic crisis in Kurdistan region of Iraq. An empirical quantitative method implemented to investigate the developed research hypotheses. The researcher applied a random sampling method, where all respondents had equal chances of being selected for the sample. The research was carried out at Sam Furniture Company in Erbil. The researcher gathered data from existing Sam office customers; however the researcher was able to collected 112 forms from customers.

\subsection{Research method}

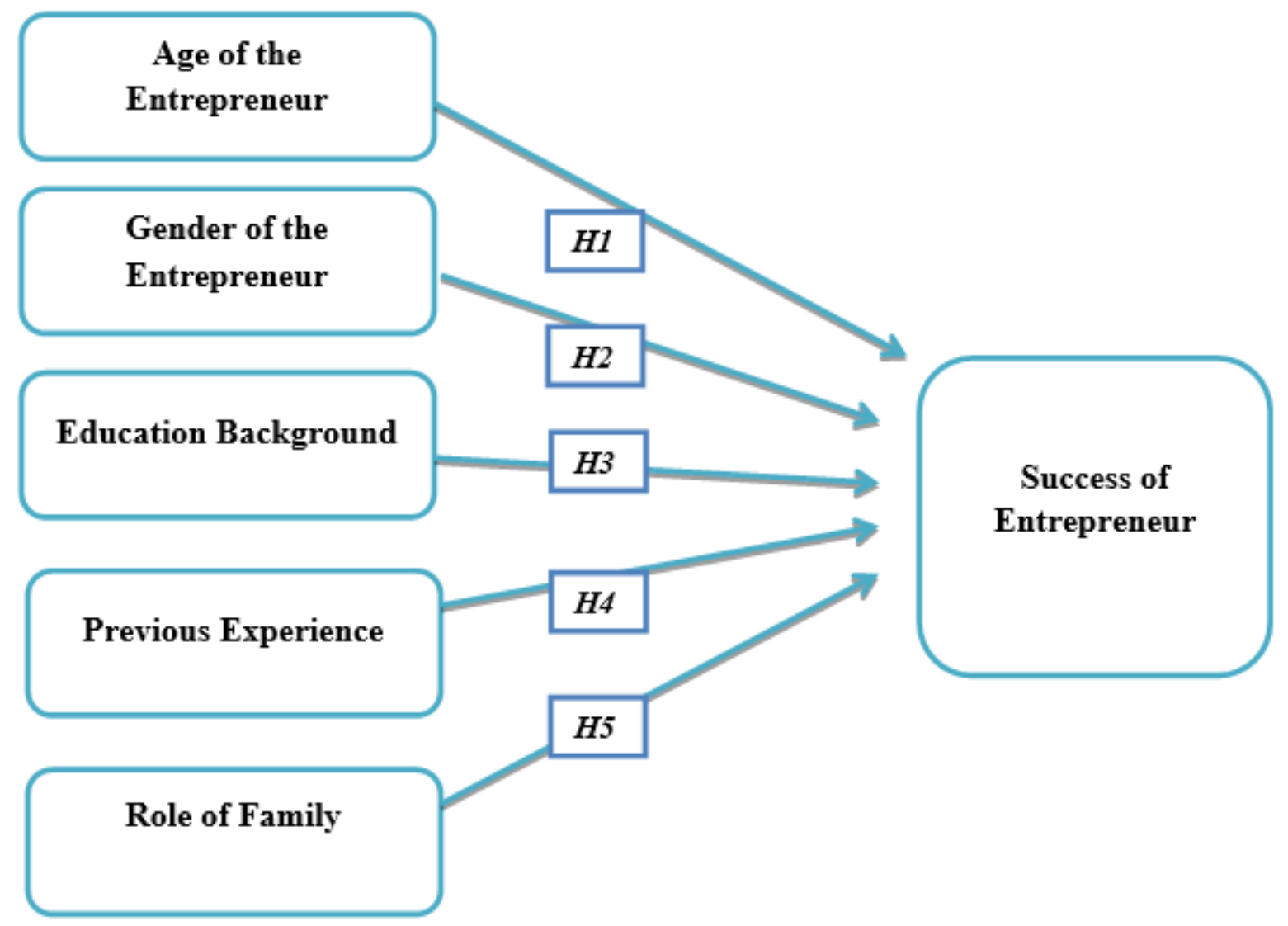

Fig.1: Research Model

\subsection{Hypotheses}


Based on the developed research model as it can be found in figure (1), the researcher was able to develop five research hypotheses as follow:

H1:Age of the Entrepreneur has a significant and positive relationship with the success of entrepreneur in furniture companies.

H2: Gender of the Entrepreneur has a significant and positive relationship with the success of entrepreneur in furniture companies.

H3:Education background of the Entrepreneur has a significant and positive relationship with the success of entrepreneur in furniture companies.

H4:Previous experience of the Entrepreneur has a significant and positive relationship with the success of entrepreneur in furniture companies.

H5:Family role of the Entrepreneur has a significant and positive relationship with the success of entrepreneur in furniture companies.

\section{RESULTS AND ANALYSIS}

Table.2: Reliability Statistics

\begin{tabular}{|l|c|c|}
\hline \multicolumn{1}{|c|}{ Items } & $\begin{array}{c}\text { Cronbach's } \\
\text { Alpha }\end{array}$ & $\begin{array}{c}\text { Number of } \\
\text { questions }\end{array}$ \\
\hline $\begin{array}{l}\text { Age of the } \\
\text { Entrepreneur }\end{array}$ & .732 & 8 \\
\hline $\begin{array}{l}\text { Gender of the } \\
\text { Entrepreneur }\end{array}$ & .726 & 9 \\
\hline $\begin{array}{l}\text { Education } \\
\text { background }\end{array}$ & .739 & 7 \\
\hline Previous & .789 & 8 \\
\hline
\end{tabular}

\begin{tabular}{|l|c|c|}
\hline experience & & \\
\hline Family role & .735 & 9 \\
\hline $\begin{array}{l}\text { Entrepreneur } \\
\text { success }\end{array}$ & .776 & 10 \\
\hline
\end{tabular}

Table 2 demonstrates the reliability tests for five independent factors (Age of the Entrepreneur, Gender of the Entrepreneur, Education background, previous experience, and Family role) Entrepreneur success as dependent factor. According to the finding of reliability tests, the value of Cronbach's Alpha for 8 items used to measure age of entrepreneur was found to be.732 which is more than 0.6 indicated that eight items used to measure age of entrepreneur was reliable, the value of Cronbach's Alpha for 9 items used to measure gender of entrepreneur was found to be.726 which is more than 0.6 indicated that nine items used to measure gender of entrepreneur was reliable, the value of Cronbach's Alpha for 7 items used to measure Education background was found to be.739 which is more than 0.6 indicated that seven items used to measure Education background was reliable, the value of Cronbach's Alpha for 8 items used to measure Previous experience was found to be.789 which is more than 0.6 indicated that eight items used to measure Previous experience was reliable,the value of Cronbach's Alpha for 9 items used to measure Family role was found to be.789 which is more than 0.6 indicated that nine items used to measure Family role was reliable, and the value of Cronbach's Alpha for 10 items used to measure Entrepreneur success was found to be.776 which is more than 0.6 indicated that ten items used to measure Entrepreneur success was reliable,

Table.3: Correlations analysis

\begin{tabular}{|l|c|c|c|c|c|c|}
\hline \multicolumn{1}{|c|}{ Factors } & Pearson & Age & Gender & Education & Previous experience & Family role \\
\hline & Pearson & $.589^{* *}$ & $.612^{* *}$ & $.708^{* *}$ & $.734^{* *}$ & $.701^{* *}$ \\
Entrepreneur & Sig.(2-tailed) & .000 & .000 & .000 & .000 & .000 \\
success & $\mathrm{N}$ & 112 & 112 & 112 & 112 & 112 \\
& & & & & & \\
\hline
\end{tabular}

Table 3 shows the correlation analysis between each five independent factors (Age of the Entrepreneur, Gender of the Entrepreneur, Education background, previous experience, and Family role) Entrepreneur success as dependent factor. The value of Pearson correlation between age of entrepreneur and entrepreneur success was $.589 * *$ this indicated that there is a significant correlation between age of entrepreneur and entrepreneur success, the value of Pearson correlation between gender of entrepreneur and entrepreneur success was $.612^{* *}$ this indicated that there is a significant correlation between gender of entrepreneur and entrepreneur success, the value of Pearson correlation between background education of entrepreneur and entrepreneur success was $.708^{* *}$ this indicated that there is a significant correlation between background education of entrepreneur and entrepreneur success, the value of Pearson correlation between previous experience of entrepreneur and entrepreneur success was $.734 * *$ this indicated that there is a significant correlation between previous experience of entrepreneur and entrepreneur success, and 
the value of Pearson correlation between family role of entrepreneur and entrepreneur success was .701** this indicated that there is a significant correlation between family role of entrepreneur and entrepreneur success.

Table.4: Model Summary

\begin{tabular}{|c|c|c|c|c|}
\hline Model & $\mathrm{R}$ & R square & Adjusted R square & Std. Error of the Estimate \\
\hline 1 & $.823 \mathrm{a}$ & .704 & .739 & .11974 \\
\hline
\end{tabular}

As seen in the Table 4 , the value of $\mathrm{R}$ square $=.704$ which indicates that $70 \%$ of variables have been explained.

Table.5: ANOVAa

\begin{tabular}{|c|c|c|c|c|c|}
\hline Model & Sum of square & Df & Mean & F & Sig. \\
\hline Regression & 5.156 & 3 & 1.035 & 129.058 & .000 \\
\hline Residual & .718 & 62 & .006 & & \\
\hline Total & 5.874 & 65 & & & \\
\hline a. Dependent Variable: Entrepreneur success \\
$\begin{array}{l}\text { b. Predictors: (Constant), Age of the Entrepreneur, Gender of the Entrepreneur, Education background, previous } \\
\text { experience, and Family role }\end{array}$ \\
\hline
\end{tabular}

Table 5 demonstrates the value of $\mathrm{F}$ for five independent factors and a dependent variable is $129.058>1$ which indicates there is a significant relationships between each five independent factors (human capital, education, political, social, and corruption) and economic growth as dependent factor.

Table.6: Coefficients

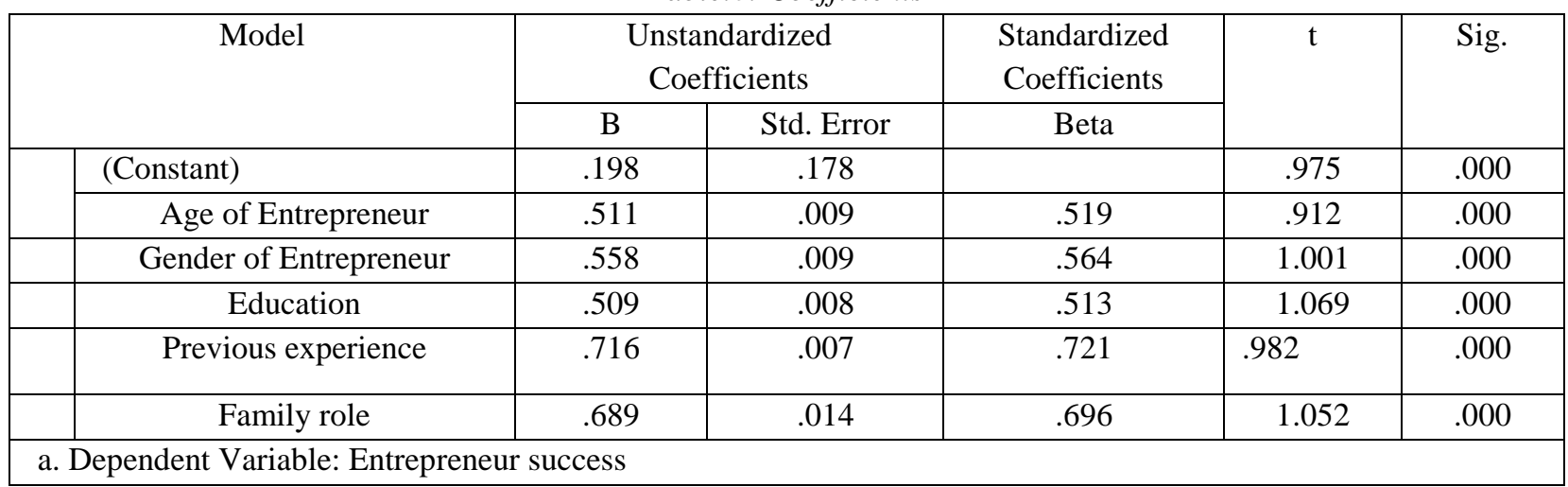

Table 6 presents the coefficients test for this study. The findings revealed that the $B$ value of for age of entrepreneur factor $=.511>0.01$, which indicated that there is a positive and significant impact of age of entrepreneur on entrepreneur success, therefore the first hypothesis is supported, the $B$ value of for gender of entrepreneur factor $=.558>0.01$, which indicated that there is a positive and significant impact of gender of entrepreneur on entrepreneur success, therefore the second hypothesis is supported, the $B$ value of for education background of entrepreneur factor = .509> 0.01, which indicated that there is a positive and significant impact of background education of entrepreneur on entrepreneur success, therefore the third hypothesis is supported, the $B$ value of for previous experience of entrepreneur factor $=.716>0.01$, which indicated that there is a positive and significant impact of previous experience of entrepreneur on entrepreneur success, therefore the fourth hypothesis is supported, and the $B$ value of for family role of entrepreneur factor $=.689>0.01$, which indicated that there is a positive and significant impact of family role of entrepreneur on entrepreneur success, therefore the fifth hypothesis is supported.

\section{CONCLUSION}

Beginning another wander is substantially harder than you might suspect and it takes any longer than you can envision. 
It is basic to approve the business idea in the commercial center before an excessive amount of time and cash is spent on a terrible thought. When all is said in done, business hatcheries encourage and help quicken the development of new pursuits. There are eight on-screen characters identified with the achievement of the private businessentrepreneur of Kurdistan recognized through the factor investigation. The variables are business person's power and market methodology, nature of business and budgetary backings, administration know-how, utilization of present day innovation, showcase availability and systems administration, government strategy and support, positive condition, and proprietor's close to home characteristics. The findings revealed that there is a positive and significant impact of age of entrepreneur on entrepreneur success, therefore the first hypothesis is supported, there is a positive and significant impact of gender of entrepreneur on entrepreneur success, therefore the second hypothesis is supported, there is a positive and significant impact of background education of entrepreneur on entrepreneur success, therefore the third hypothesis is supported, there is a positive and significant impact of previous experience of entrepreneur on entrepreneur success, therefore the fourth hypothesis is supported, and there is a positive and significant impact of family role of entrepreneur on entrepreneur success, therefore the fifth hypothesis is supported. However, it was found that the highest value obtained was by previous experience of entrepreneur in running furniture companies in Erbil on the other hand the lowest value of background education of entrepreneur in establishing and expanding a furniture company in Erbil.

\section{REFERENCES}

[1] Bruton, G., Khavul, S., Siegel, D., \& Wright, M. (2015). New financial alternatives in seeding entrepreneurship: Microfinance, crowdfunding, and peer-to-peer innovations. Entrepreneurship Theory and Practice, 39(1), 9-26.

[2] Glaeser, E. L., Kerr, S. P., \& Kerr, W. R. (2015). Entrepreneurship and urban growth: An empirical assessment with historical mines. Review of Economics and Statistics, 97(2), 498-520.

[3] Bae, T. J., Qian, S., Miao, C., \&Fiet, J. O. (2014). The relationship between entrepreneurship education and entrepreneurial intentions: A meta-analytic review. Entrepreneurship theory and practice, 38(2), 217-254.

[4] Fayolle, A., \&Gailly, B. (2015). The impact of entrepreneurship education on entrepreneurial attitudes and intention: Hysteresis and persistence. Journal of Small Business Management, 53(1), 75-93.

[5] Davidsson, P. (2015). Entrepreneurial opportunities and the entrepreneurship nexus: A reconceptualization. Journal of Business Venturing, 30(5), 674-695.

[6] Ács, Z. J., Autio, E., \&Szerb, L. (2014). National systems of entrepreneurship: Measurement issues and policy implications. Research Policy, 43(3), 476-494.

[7] Decker, R., Haltiwanger, J., Jarmin, R., \& Miranda, J. (2014). The role of entrepreneurship in US job creation and economic dynamism. Journal of Economic Perspectives, 28(3), 3-24.

[8] Terjesen, S., Hessels, J., \& Li, D. (2016). Comparative international entrepreneurship: A review and research agenda. Journal of Management, 42(1), 299-344.

[9] Boh, W. F., De-Haan, U., \& Strom, R. (2016). University technology transfer through entrepreneurship: faculty and students in spinoffs. The Journal of Technology Transfer, 41(4), 661-669.

[10] Piperopoulos, P., \&Dimov, D. (2015). Burst bubbles or build steam? Entrepreneurship education, entrepreneurial self-efficacy, and entrepreneurial intentions. Journal of Small Business Management, 53(4), 970-985.

[11] Stephan, U., Uhlaner, L. M., \& Stride, C. (2015). Institutions and social entrepreneurship: The role of institutional voids, institutional support, and institutional configurations. Journal of International Business Studies, 46(3), 308-331.

[12] Arend, R. J., Sarooghi, H., \&Burkemper, A. (2015).Effectuation as ineffectual?Applying the $3 \mathrm{E}$ theory-assessment framework to a proposed new theory of entrepreneurship. Academy of management Review, 40(4), 630-651.

[13] Read, S., Sarasvathy, S. D., Dew, N., \&Wiltbank, R. (2016). Response to Arend, Sarooghi, and Burkemper (2015): Cocreating effectual entrepreneurship research. Academy of management Review, 41(3), 528536.

[14] Siqueira, A. C. O., Webb, J. W., \&Bruton, G. D. (2016).Informal entrepreneurship and industry conditions. Entrepreneurship Theory and Practice, 40(1), 177-200.

[15]Choi, N., \&Majumdar, S. (2014). Social entrepreneurship as an essentially contested concept: Opening a new avenue for systematic future research. Journal of business venturing, 29(3), 363376. 
[16] McKeever, E., Jack, S., \& Anderson, A. (2015). Embedded entrepreneurship in the creative reconstruction of place. Journal of Business Venturing, 30(1), 50-65.

[17] Acs, Z. J., Estrin, S., Mickiewicz, T., \&Szerb, L. (2018). Entrepreneurship, institutional economics, and economic growth: an ecosystem perspective. Small Business Economics, 1-14.

[18] Coviello, N. E., Jones, M. V., \& McDougall-Covin, P. P. (2015). Is International Entrepreneurship research a viable spin-off from its parent disciplines. Rethinking entrepreneurship: debating research orientations, 78100.

[19] Fitz-Koch, S., Nordqvist, M., Carter, S., \& Hunter, E. (2018). Entrepreneurship in the agricultural sector: A literature review and future research opportunities. Entrepreneurship Theory and Practice, 42(1), 129-166.

[20] Nabi, G., Walmsley, A., Liñán, F., Akhtar, I., $\&$ Neame, C. (2018). Does entrepreneurship education in the first year of higher education develop entrepreneurial intentions? The role of learning and inspiration. Studies in Higher Education, 43(3), 452467.

[21] Entrialgo, M., \& Iglesias, V. (2018). Are the Intentions to Entrepreneurship of Men and Women Shaped Differently? The Impact of Entrepreneurial RoleModel Exposure and Entrepreneurship Education. Entrepreneurship Research Journal, 8(1), 1-14.

[22] Hornsby, J. S., Messersmith, J., Rutherford, M., \& Simmons, S. (2018). Entrepreneurship Everywhere: Across Campus, Across Communities, and Across Borders. Journal of Small Business Management, 56(1), 4-10.

[23] Shelton, L. M., \&Minniti, M. (2018).Enhancing product market access: Minority entrepreneurship, status leveraging, and preferential procurement programs. Small Business Economics, 50(3), 481-498.

[24] Henry, E. Y., Dana, L. P., \& Murphy, P. J. (2018). Telling their own stories: Māori entrepreneurship in the mainstream screen industry. Entrepreneurship \& Regional Development, 30(1-2), 118-145.

[25] Hlady-Rispal, M., \&Servantie, V. (2018). Deconstructing the way in which value is created in the context of social entrepreneurship. International Journal of Management Reviews, 20(1), 62-80.

[26] Coviello, N., \&Tanev, S. (2017). Initiating a New Research Phase in the Field of International Entrepreneurship: An Interview with Professor Nicole
Coviello. Technology Innovation Management Review, 7(5).

[27] Acs, Z. J., Estrin, S., Mickiewicz, T., \&Szerb, L. (2018). Entrepreneurship, institutional economics, and economic growth: an ecosystem perspective. Small Business Economics, 1-14.

[28] Huq, A., \& Gilbert, D. (2017). All the world'sa stage: transforming entrepreneurship education through design thinking. Education+ Training, 59(2), 155-170.

[29] Berglund, H., \&Korsgaard, S. (2017). Opportunities, time, and mechanisms in entrepreneurship: On the practical irrelevance of propensities. Academy of Management Review, 42(4), 730-733.

[30]Nabi, G., Liñán, F., Fayolle, A., Krueger, N., \&Walmsley, A. (2017). The impact of entrepreneurship education in higher education: A systematic review and research agenda. Academy of Management Learning \& Education, 16(2), 277-299.

[31]Lerner, D. A., Hunt, R. A., \&Dimov, D. (2018). Action! Moving beyond the intendedly-rational logics of entrepreneurship. Journal of Business Venturing, 33(1), 52-69.

[32] Stuetzer, M., Audretsch, D. B., Obschonka, M., Gosling, S. D., Rentfrow, P. J., \& Potter, J. (2017).Entrepreneurship culture, knowledge spillovers and the growth of regions. Regional Studies, 1-11.

[33] Belz, F. M., \& Binder, J. K. (2017). Sustainable entrepreneurship: a convergent process model. Business Strategy and the Environment, 26(1), 1-17.

[34] Nabi, G., Walmsley, A., Liñán, F., Akhtar, I., \&Neame, C. (2018). Does entrepreneurship education in the first year of higher education develop entrepreneurial intentions? The role of learning and inspiration. Studies in Higher Education, 43(3), 452467.

[35] Danakol, S. H., Estrin, S., Reynolds, P., \&Weitzel, U. (2017). Foreign direct investment via M\&A and domestic entrepreneurship: blessing or curse?. Small Business Economics, 48(3), 599-612.

[36] Campbell, B. A., Kryscynski, D., \& Olson, D. M. (2017).Bridging strategic human capital and employee entrepreneurship research: A labor market frictions approach. Strategic Entrepreneurship Journal, 11(3), 344-356.

[37] Shelton, L. M., \&Minniti, M. (2018).Enhancing product market access: Minority entrepreneurship, status leveraging, and preferential procurement programs. Small Business Economics, 50(3), 481-498. 
[38] McKenny, A. F., Allison, T. H., Ketchen, D. J., Short, J. C., \& Ireland, R. D. (2017). How Should Crowdfunding Research Evolve? A Survey of the Entrepreneurship Theory and Practice Editorial Board. Entrepreneurship Theory and Practice, 41(2), 291-304.

[39] Huang, L., \& Knight, A. P. (2017). Resources and relationships in entrepreneurship: an exchange theory of the development and effects of the entrepreneurinvestor relationship. Academy of Management Review, 42(1), 80-102.

[40] Wiklund, J., Yu, W., Tucker, R., \& Marino, L. D. (2017). ADHD, impulsivity and entrepreneurship. Journal of Business Venturing, 32(6), 627-656.

[41] McKenzie, D. (2017). Identifying and spurring highgrowth entrepreneurship: experimental evidence from a business plan competition. American Economic Review, 107(8), 2278-2307.

[42] Hlady-Rispal, M., \& Servantie, V. (2018). Deconstructing the way in which value is created in the context of social entrepreneurship. International Journal of Management Reviews, 20(1), 62-80.

[43] Si, S., Cullen, J., Ahlstrom, D., \& Wei, J. (2018). Special Issue: Business, Entrepreneurship and Innovation toward Poverty Reduction: Papers for the Special Issue, deadline September 15, 2018. 